\title{
Utility Values of Extensive Lawns Fertilized with Sewage Sludge
}

\author{
Kazimierz Grabowski ${ }^{1 *}$, Agata Głowacka-Gil ${ }^{1}$, Stefan Grzegorczyk ${ }^{1}$, \\ Krystyna Grabowska ${ }^{2}$
}

\author{
'Department of Grassland and Green Space Management \\ Received: December 8, 2014 \\ Accepted: April 1, 2015
}

${ }^{2}$ Department of Water, Climate and Environmental Management

University of Warmia and Mazury, Plac Łódzki 1, 10-724 Olsztyn, Poland

\begin{abstract}
This paper presents the results of studies carried out in 2006-08 on the impact of sewage sludge on the utility values of grass sward. The study was conducted with different doses of sewage sludge $(0,70,140,210$,

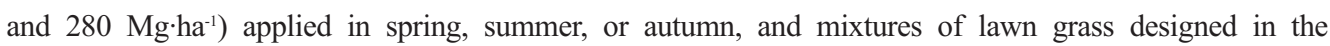
Department of Grassland at the University of Warmia and Mazury in Olsztyn, which were sown in spring, summer, or autumn. Winter survival, turfness, colour, perfection of leaf blades, and general appearance of grass sward on a nine-point scale were evaluated during vegetation seasons. It was demonstrated that incremental doses of sewage sludge positively impacted the examined characteristics, especially when fertilization was applied in spring. Spring sowing of lawn grass seeds was also found to be better. It was shown that both tested mixtures (fescue and bluegrass) are useful for sowing extensive lawns, although the fescue mixture had more favourable parameters.
\end{abstract}

Keywords: extensive lawns, sewage sludge, utility values of grass sward

\section{Introduction}

Deposition of sewage sludge on landfills is a disturbing and ever-present problem due to the risk such sludge may pose to the environment. Its utilization is a difficult issue as it may contain toxic compounds such as heavy metals and sanitary contamination [1]. However, apart from these harmful components, valuable nutrients also have been identified in sewage sludge. Municipal sewage sludge is a potential source of organic and mineral matter, for instance nitrogen, phosphorus, magnesium, calcium, and microelements that beneficially impact the physiological processes in plant and soil microorganisms [2]. Municipal sewage sludge is thus regarded as a non-conventional fertilizer; it is a waste product that should be recycled [3, 4]. Baran [2]

*e-mail: kazikg@uwm.edu.pl believe that the environmental use of sewage sludge is natural and less expensive than its deposition and combustion. If sewage sludge does not contain microbiological contaminants and an excessive amount of heavy metals, it may be used directly for plant fertilization [4-7]. Plants may play an important role in the transformation of physical and chemical properties of environmentally used sewage sludge. Among many plant species, those belonging to the Poaceae family (grasses) are especially useful. Soil fertilized with sewage sludge may represent an excellent substrate for grass lawns. By selecting an optimal dose of sewage sludge and a type of lawn grass mixture, one may design a lawn that has both aesthetic and ecological functions [8].

Extensive lawns that are located along roads or as green lines separating highway lanes and areas devastated by industrial and municipal activities are of particular concern [6]. Together with the development of communications, 
Table 1. The average air temperature and precipitation volume according to data from the Meteorological Station in Tomaszkowo (2006-08).

\begin{tabular}{|c|c|c|c|c|c|c|c|c|}
\hline \multirow{2}{*}{ Month } & \multicolumn{4}{|c}{ Average air temperature $\left({ }^{\circ} \mathrm{C}\right)$} & \multicolumn{5}{c|}{ Precipitation volume $(\mathrm{mm})$} \\
\cline { 2 - 9 } & 2006 & 2007 & 2008 & $1961-2000$ & 2006 & 2007 & 2008 & $1961-2000$ \\
\hline I & -8.5 & 2.6 & 0.4 & -2.3 & 19.8 & 115.4 & 66.2 & 25.2 \\
\hline II & -3.3 & -2.5 & 2.4 & -1.5 & 27.6 & 23.5 & 24.7 & 23.6 \\
\hline III & -2.5 & 5.6 & 2.8 & 1.0 & 6.0 & 27.8 & 52.4 & 28.7 \\
\hline IV & 7.3 & 7.5 & 7.5 & 7.5 & 25.6 & 24.7 & 31.4 & 40.8 \\
\hline V & 12.5 & 13.8 & 12.3 & 12.7 & 89.2 & 93.5 & 27.0 & 66.5 \\
\hline VI & 16.0 & 17.7 & 16.8 & 16.3 & 79.2 & 88.1 & 32.7 & 65.2 \\
\hline VII & 20.9 & 17.7 & 18.4 & 17.1 & 29.3 & 173.7 & 57.7 & 89.1 \\
\hline VIII & 17.2 & 18.3 & 17.5 & 17.1 & 165.0 & 68.0 & 102.1 & 67.9 \\
\hline IX & 14.8 & 12.6 & 11.8 & 12.1 & 51.0 & 57.9 & 22.9 & 32.6 \\
\hline X & 9.9 & 7.5 & 8.6 & 7.9 & 38.3 & 30.2 & 82.8 & 42.7 \\
\hline XI & 5.1 & 1.3 & 4.0 & 2.3 & 79.3 & 33.8 & 29.4 & 40.0 \\
\hline XII & 4.3 & 3.0 & 0.1 & -1.4 & 45.4 & 35.0 & 35.1 & 29.3 \\
\hline I-XII & 7.8 & 8.8 & 8.6 & 7.4 & 655.7 & 771.6 & 564.4 & 551.6 \\
\hline IV-IX & 14.8 & 14.6 & 14.1 & 13.8 & 439.3 & 505.9 & 273.8 & 362.1 \\
\hline
\end{tabular}

improvements of infrastructure, and building of housing estates, the problems associated with increasing the acreage of green zones in degraded areas are only increasing. Greenery should be an essential element contributing to the climate of a modern city and it can be fertilized with biowastes that [5], as a source of fertilizing components, create favourable conditions for the regular growth of lawn grass and simultaneously benefit the soil. Reprocessing of sludge, namely using it to set lawns, brings economic and, above all, ecological benefits. This eliminates the need for mineral fertilization of lawns, which is not neutral to the environment [9].

The objective of our studies was to determine the impact of diversified doses of sewage sludge and the timing of their use, as well as the timing of sowing and types of lawn grass mixtures (fescue and bluegrass) on the utility values of extensively-used grass sward.

\section{Experimental Procedures}

\section{Description of the Object}

The Olsztynskie Lakeland is characterized by substantial ecological diversity that mainly concerns landscape features, plant cover, and climatic factors [10]. The latter, with their thermal and humidity conditions, are favourable for the setting greeneries. Table 1 presents the meteorological data recorded on the Meteorological Station in Tomaszkowo in 2006-08. The numbers in the table demonstrate that in all studied years both the average annual temperatures and precipitation volume were higher than the means for the period 1961-2000. In 2006, the average air temperature and precipitation volume were higher than the mean for the multi-annual period by $0.4^{\circ} \mathrm{C}$, and as much as $104.1 \mathrm{~mm}$, respectively, which, in general, positively impacted the growth and development of the studied species (cultivars) of lawn grass. However, low temperatures at the beginning of the year (January, February, March) deteriorated their winter survival; January 2006 was the coldest month $\left(-8.5^{\circ} \mathrm{C}\right)$ in the studied period. In addition, a very small volume of precipitation in March $(6.0 \mathrm{~mm})$ contributed to the late onset of vegetation. In contrast, favourable (close to the standard) values of temperature and precipitation in the next quarter (IV-VI) - especially a high level of precipitation in May (89.2 $\mathrm{mm})$ - positively influenced the re-growth of grass and the degree of turfness. In the summer period (JulySeptember), higher (than the standard) temperature (particularly in July and September) and precipitation (especially in August and September) favoured further grass vegetation and heat and abundant precipitation in November and December extended the period of vegetation.

The year 2007 was warm and humid with a high average annual temperature of $8.8^{\circ} \mathrm{C}\left(7.4^{\circ} \mathrm{C}\right.$ in the multi-annual period) as well as a high level of precipitation at $771.6 \mathrm{~mm}$ (the average is $551.5 \mathrm{~mm}$ ). Such conditions (heat and humidity) lasting until September were favourable for winter survival and beneficially impacted the degree of turfness, colour, slenderness of leaves, and, thus, the attractiveness of the grass sward. 
Table 2. Species composition of the lawn grass mixtures.

\begin{tabular}{|l|c|c|c|}
\hline \multirow{2}{*}{ Species } & \multirow{2}{*}{ Cultivar } & \multicolumn{2}{c|}{ \% content of seeds in mixtures } \\
\cline { 2 - 4 } & & Fescue mixture A & Bluegrass mixture B \\
\hline Festuca rubra L., ssp. commutata Gaud. & Dorosa & 10 & 10 \\
\hline Festuca rubra L., ssp. trichophylla Gaud. & Napoli & 25 & 10 \\
\hline \multirow{2}{*}{ Festuca rubra L., ssp. rubra Hack. } & Barma & 10 & 5 \\
\hline \multirow{3}{*}{ Poa pratensis L. } & Gross & 10 & 15 \\
\cline { 2 - 4 } & Bila & 15 & 20 \\
\hline Festuca ovina L., sensu lato & Nandu & 10 & 20 \\
\hline Agrostis capillaris Huds. & Alicja & - & 10 \\
\hline Lolium perenne L. & Sima & 2 & 2 \\
\hline
\end{tabular}

The last three months of 2007 were cooler and drier (except for December), which inhibited plant vegetation.

In general, weather conditions in 2008 positively impacted the growth and development of lawn grass. Drops in air temperature below the average were recorded only in May and September, whereas precipitation that was lower than normal from April to July and in September and November hindered the growth of studied species (cultivars) of lawn grass. Water deficits were, however, compensated by high precipitation in August (150\%) and October (194\%), which improved the condition of grass.

These agricultural-climatic conditions were the background for vegetation of the grass species (cultivars) within the framework of a precise four-factor microplot ( $1 \mathrm{~m} \times$ $1 \mathrm{~m}$ ) experiment using a "split-split-block" method in the Teaching and Experimental Centre of the University of Warmia and Mazury in Olsztyn. The experiment was conducted in four repetitions on anthropogenic soil of light loamy sand. The following components were analyzed:

- Different doses of sludge: 0 (control), 70, 140, 210, and $280 \mathrm{Mg} \cdot \mathrm{ha}^{-1}$, constituting factor I

- Mixtures of lawn grass (fescue and bluegrass) designed in the Department of Grassland at the University of Warmia and Mazury, serving as factor II (Table 2)

- Factor III included the time-points of sewage sludge application: in autumn (29 October 2004), in spring (28 April 2005), and in summer (30 July 2005)

- Factor IV included the time-points of grass mixture sowing: in spring (23 and 24 May 2005), in summer (1 August 2005), and in autumn (9 September 2005)

Soil was fertilized with sewage sludge and mixed to approximately $10 \mathrm{~cm}$ deep. The plots that were fertilized with sewage sludge in autumn were sown with a mixture of lawn grass at two time-points: in autumn and in spring. The plots that were fertilized with sewage sludge in spring were also sown with the mixtures of lawn grass at two timepoints: in spring and in summer. The plots fertilized in summer were sown in summer and autumn.
Table 3. Select soil physico-chemical properties.

\begin{tabular}{|c|c|c|c|}
\hline \multirow{5}{*}{$\begin{array}{l}\text { Content of } \\
\text { absorbable } \\
\text { components }\end{array}$} & $\mathrm{P}$ & \multirow{5}{*}{$\mathrm{g} \cdot \mathrm{kg}^{-1}$} & 16.28 \\
\hline & $\mathrm{K}$ & & 9.13 \\
\hline & $\mathrm{Mg}$ & & 7.8 \\
\hline & $\mathrm{Ca}$ & & 0.71 \\
\hline & $\mathrm{Na}$ & & 0.01 \\
\hline \multicolumn{2}{|l|}{ Total N } & \multirow{2}{*}{$\%$} & 2.59 \\
\hline \multicolumn{2}{|c|}{ Organic matter } & & 8.25 \\
\hline \multicolumn{2}{|l|}{$\mathrm{pH}_{\mathrm{KCl}}$} & - & 7.30 \\
\hline \multicolumn{2}{|l|}{$\mathrm{pH}_{\mathrm{H}_{2} \mathrm{O}}$} & - & 7.36 \\
\hline
\end{tabular}

Seeds of lawn grass were broadcast "crosswise" and the surfaces of the plots were then raked up, rolled, and covered with a thin layer $(0.2 \mathrm{~cm})$ of dry sand.

The upper layer of soil had a very high content of absorbable phosphorus (16.28 $\left.\mathrm{g} \cdot \mathrm{kg}^{-1}\right)$ and magnesium $\left(7.8 \mathrm{~g} \cdot \mathrm{kg}^{-1}\right)$, an average content of potassium $\left(9.13 \mathrm{~g} \cdot \mathrm{kg}^{-1}\right)$ and calcium $\left(0.71 \mathrm{~g} \cdot \mathrm{kg}^{-1}\right)$, and a low concentration of sodium $\left(0.01 \mathrm{~g} \cdot \mathrm{kg}^{-1}\right)$. The content of total nitrogen was $2.59 \% \mathrm{DM}$ and the content of organic matter was $8.25 \%$. The reaction of soil was neutral (Table 3 ).

Municipal sewage sludge originated from the Lyna Municipal Sewage Treatment Plant in Olsztyn. The content of dry matter in sewage sludge was $27.61 \%$; sewage sludge contained $32.16 \%$ of organic matter and $\mathrm{pH}_{\mathrm{KCl}}$ was 8.49 . The content of nitrogen in sewage sludge was higher $(3.33 \%$ $\mathrm{DM})$ than in organic fertilizers and the concentration of other macroelements was as follows: $\mathrm{P}-1.44, \mathrm{~K}-0.12, \mathrm{Na}$ $-0.16, \mathrm{Ca}-2.79$, and $\mathrm{Mg}-0.50 \% \mathrm{DM}$, whereas for heavy metals the content was: $\mathrm{Zn}-1340, \mathrm{Cu}-251, \mathrm{~Pb}-52.60, \mathrm{Ni}$ - 44.50, $\mathrm{Cr}-47.70, \mathrm{Cd}-3.60$, and $\mathrm{Hg}-10 \mathrm{mg} \cdot \mathrm{kg}^{-1} \mathrm{DM}$, 
and did not exceed the standards specified in the Regulation of the Minister of Environment of 1 August 2002 (J.Law.02.134.1140).

In the years of full usage (2006-08), the evaluation was carried out in spring, summer, and autumn according to the COBORU methodology [11]:

- Winter survival (in spring) on a 9-point scale, where 1 denotes "very poor wintering" (lack of plants), 5 indicates "average wintering" (50\% of plant loss), and 9 stands for "very good wintering" (without plant loss)

- Turfness (in spring, summer, and autumn) on a 9-point scale, where 1 denotes "poor turfness" (lack of plants) 0 is $5 \%$ of cover, 5 indicates "acceptable turfness" (average density" $41-60 \%$ of cover), and 9 stands for "very good turfness" (ideal blanket) 96-100\% of cover

- Colour, i.e. the colour of leaves (in spring, summer, and autumn) on a 9-point scale according to the RHS Colour Chart, London 1996

- Perfection of leaves, i.e. their slenderness (in spring, summer, and autumn) on a 9-point scale, where 1 denotes “a very wide leaf” (coarse), 5 indicates “an intermediate leaf" (template), and 9 stands for "a very slender leaf' (the most subtle)

- General appearance, i.e. the appearance of grass sward (in spring, summer, and autumn) on a 9-point scale, where 1 denotes "poor appearance" (grass sward without quality), 5 indicates "acceptable appearance" (average grass sward), and 9 stands for "very good appearance" (appealing grass sward)

The frequency of mowing depended on the timing of sowing of lawn grass seeds and re-growth rate. In the years when the grass sward was used, it was mowed at $6 \mathrm{~cm}$ eight times during the vegetation season and the collected biomass was removed.

The recorded results on the utility values of lawn grass mixtures were statistically analyzed. Homogenous groups were determined with Duncan's test at $\mathrm{p}=0.05$ (the level of significance).

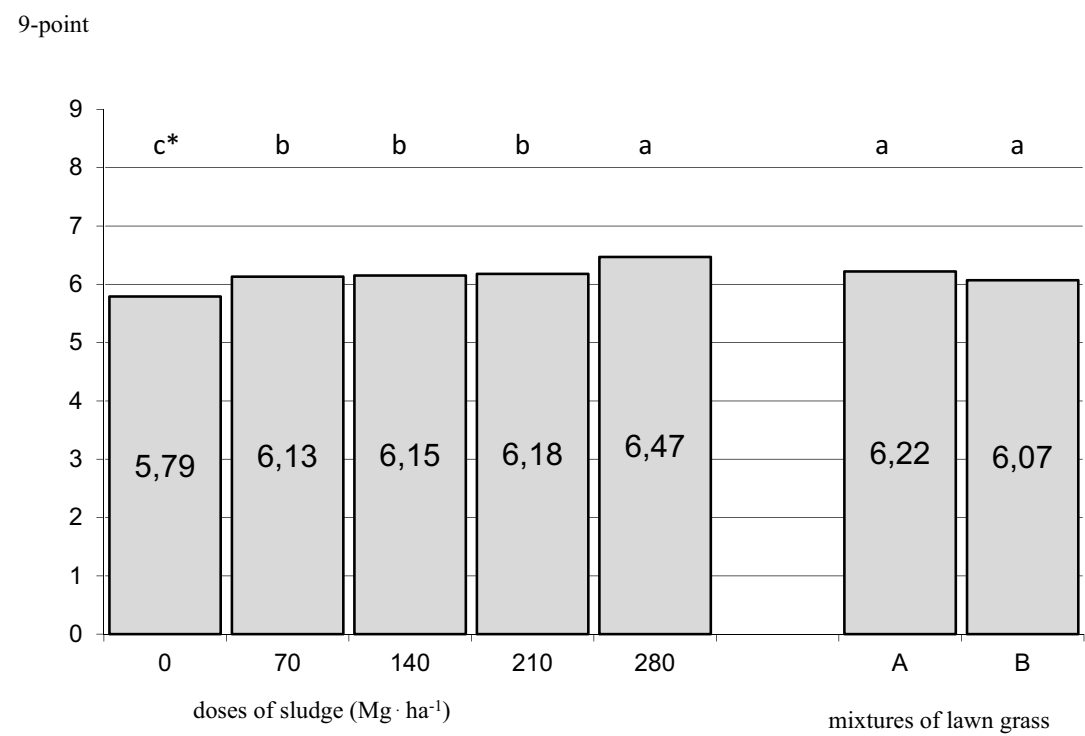

9-point

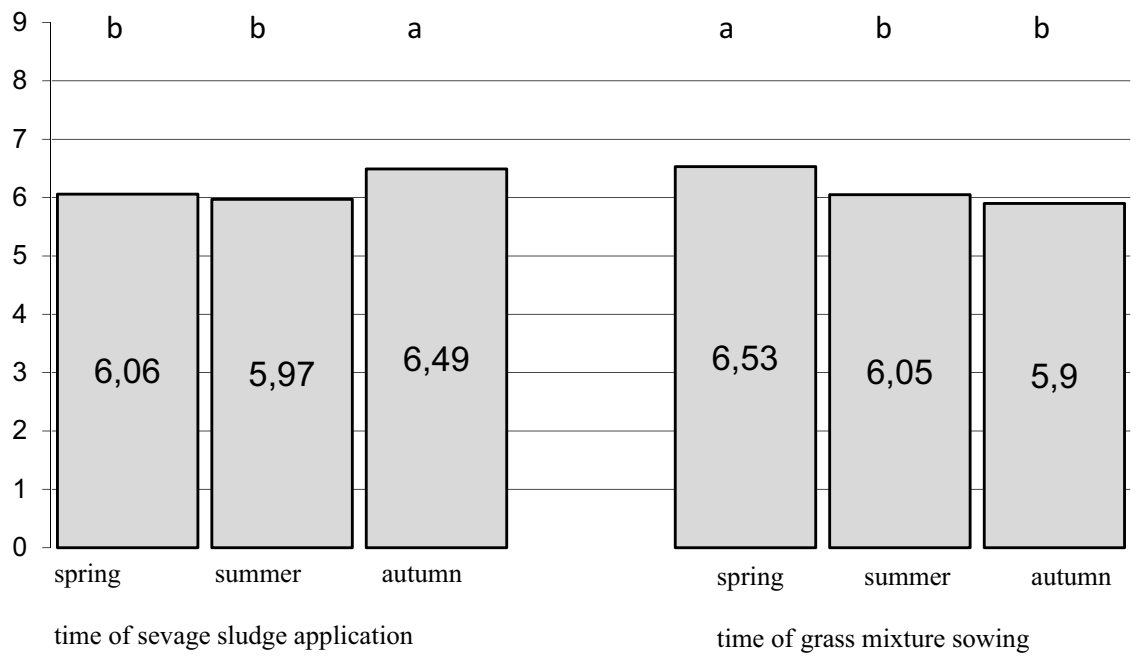

Fig. 1. The effects of sewage sludge dose and mixtures of lawn grass as well as the term of sewage sludge application and the seed sowing on winter survival of sward (mean values from 2006-08).

*a-c-Homogenous groups by Duncan's test 


\section{Results and Discussion}

The conducted studies on the impact of diversified doses of sewage sludge and timing of the application on the utility values of extensive lawns complement the existing knowledge on this subject. In Poland, sewage sludge management is not completely regulated and the environmental use of bio-wastes (utilization) is one of the future solutions to this problem. Studies by Garling and Boehm [12], Loschinkohl and Boehm [13], and Łachacz et al. [9] indicate the large potential for the use of sludge in the setting of laws.

Winter survival of plants is one of the factors that helps maintain the good quality of grass sward. This is a utility feature that has an important role under climatic conditions in Poland, especially in northeastern Poland. Winter survival is a result of the impact of low temperatures, snow, and winter diseases on grass sward.
In the years of full usage, lawn grasses overwintered best after the application of the highest sewage sludge dose (Fig. 1). Winter survival deteriorated (from average to good) along with decreasing doses and the worst wintering results (on average according to the scale: $50 \%$ of plant loss) were recorded on the control object.

The analyzed lawn grass mixtures (fescue and bluegrass) overwintered similarly, yet the fescue mixture with red fescue as the predominant species showed slightly better hardiness (Fig. 1). However, this was not confirmed in studies by Domański [14], who believes that Poa pratensis $\mathrm{L}$. is the species that is more resistant than Festuca rubra $\mathrm{L}$. to unfavourable climatic conditions, namely long-lasting snow cover or low air temperatures.

Fig. 1 also shows that sewage sludge that was applied in autumn had the best impact on winter survival (6.49 on the 9-point scale) of lawn grass sown in spring.

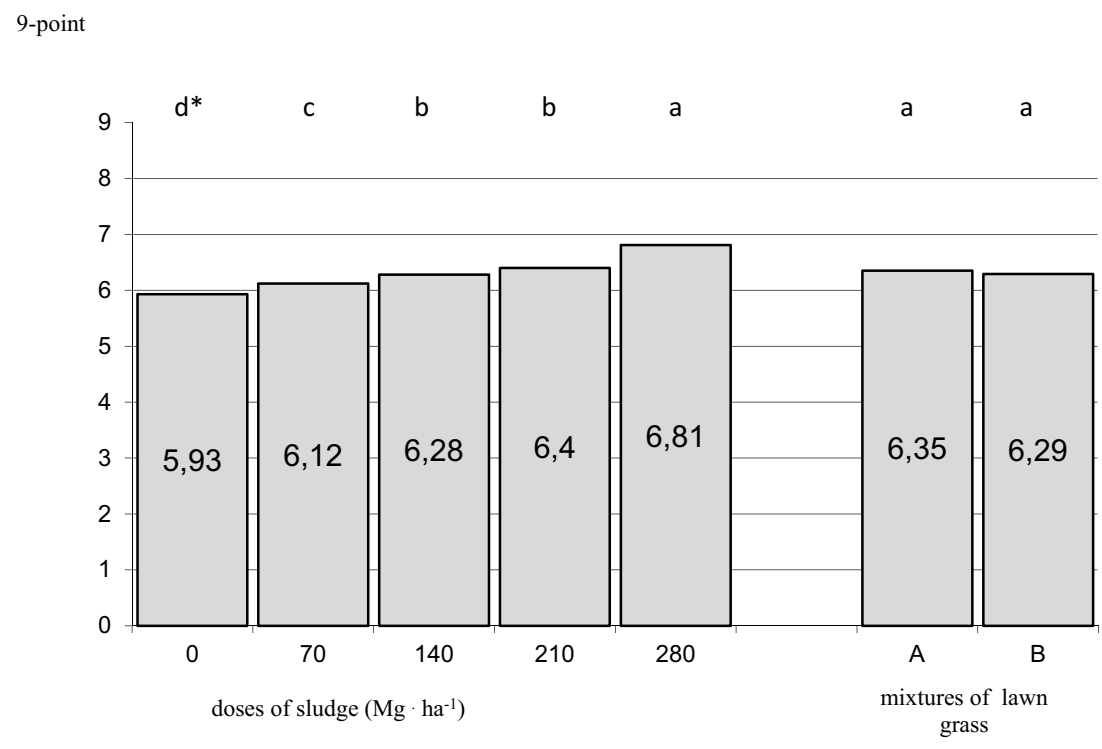

9-point

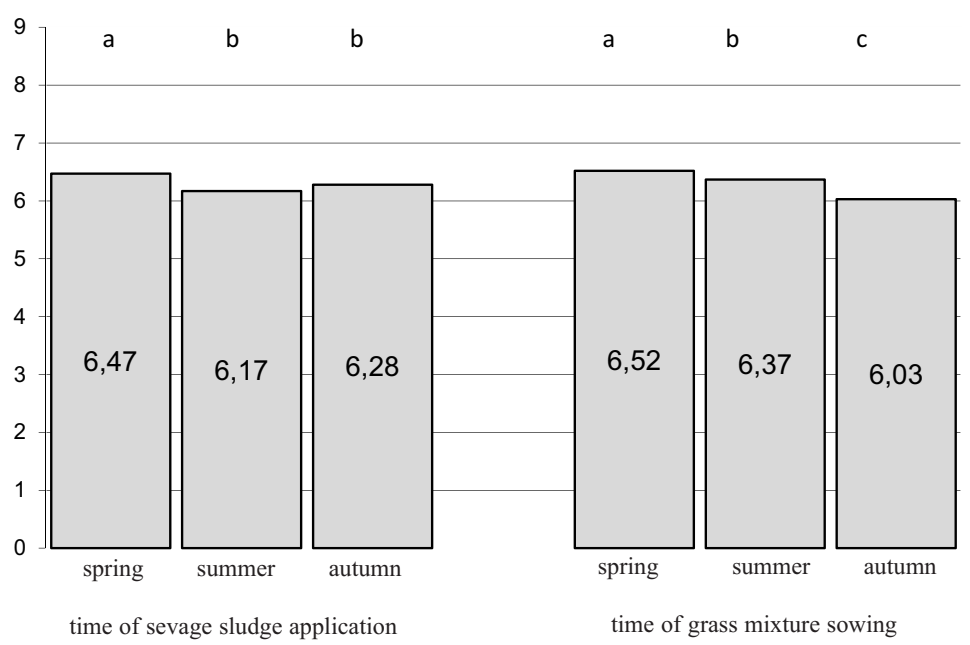

Fig. 2. The effects of sewage sludge dose and mixtures of lawn grass as well as the term of sewage sludge application and seed sowing on turfness of sward (mean values from 2006-08).

*a-d - Homogenous groups by Duncan's test 
The quality of lawns, especially their tartness (which is understood as the cover of ground with grass stalks and live leaf blades) depends on numerous factors. The most important ones include correct substrate preparation, accurate selection of grass species and cultivars (depending on the target usage of lawns), and optimal care. Turfness and general appearance are important characteristics that are taken into account when grass sward and grass cultivars are evaluated for their use as lawns $[8,11,14,15]$. Both the species and grass cultivars exert a large impact on the density of sward.

The evaluation and classification of lawns carried out in spring, summer, and autumn demonstrated that there was a distinct impact of applied sewage sludge on the degree of cover with grass stalks and grass leaf blades. During the period of full use of the lawn, the degree of plot cover with plants increased together with incremental doses of sewage sludge (Fig. 2). The degree of turfness improved throughout the entire vegetation period with an increasing level of fertilization, which is reflected in studies by Linde and Hepner [16]. In the studied period (2006-08), the dose of $280 \mathrm{Mg} \cdot \mathrm{ha}^{-1}$ of sewage sludge was found to be the most beneficial (Fig. 2) as, at this dose, the degree of turfness was acceptable-to-good (6.81 on a 9-point scale).

Statistical analysis also confirmed the impact of the timing of sewage sludge application on the degree of turfness in the years of full usage (Fig. 2). The best turfness was recorded on the plots on which sewage sludge was applied in spring (6.47 on the 9-point scale) with autumn fertilization located on the next place (6.28).

In the studied years, the status of turfness of both lawn grass mixtures was on a comparable level, although the density of grass sward for the fescue mixture was slightly more beneficial. The degree of turfness is clearly determined by the species-specific properties. The more beneficial density of fescue sward resulted mainly from a higher proportion of Festuca rubra L., ssp. commutata seeds in the

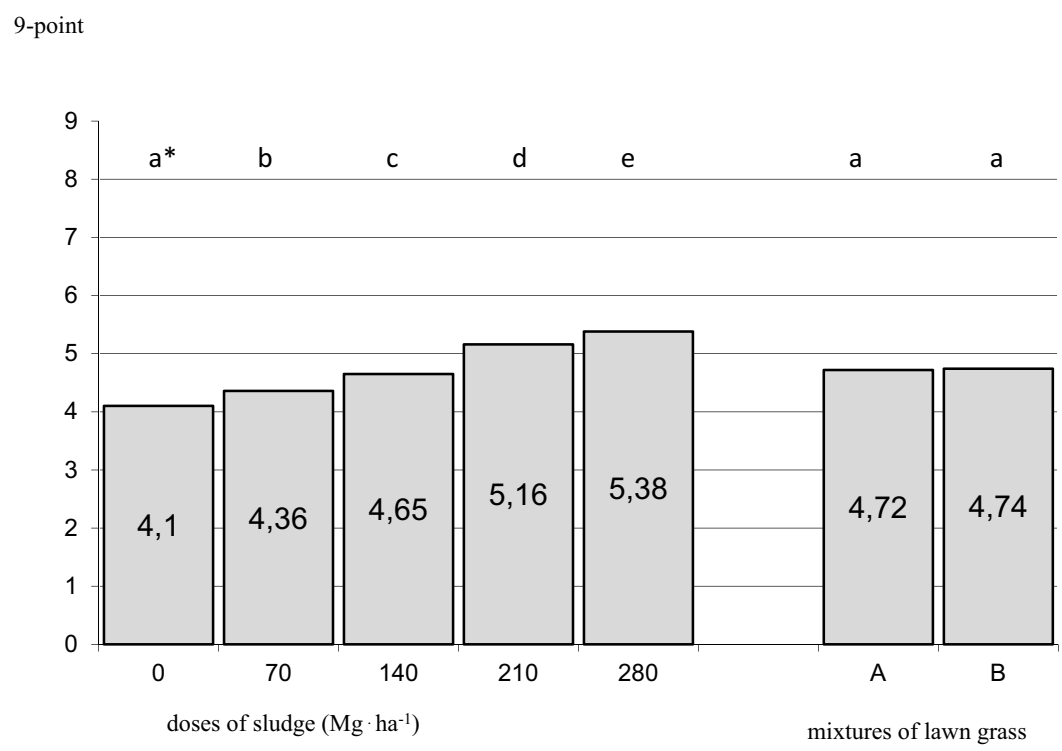

9-point

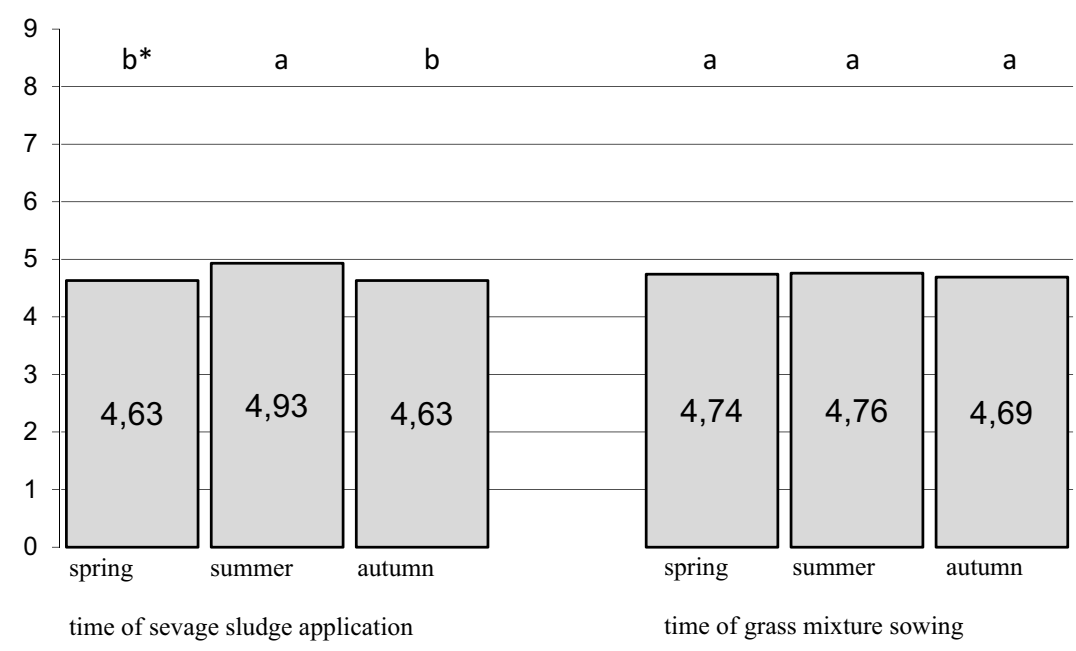

Fig. 3. The effects of sewage sludge dose and mixtures of lawn grass as well as the term of sewage sludge application and seed sowing on colour of sward (mean values from 2006-08).

*a-e - Homogenous groups by Duncan's test 
mixture. Studies by Radkowski and Styrc [17] confirmed the better turfness of this subspecies. Lower turfness grades for the bluegrass mixture result from the morphological features, especially from slow growth and development of this species. Similar conclusions were drawn, among others, by Prończuk S. and Prończuk M. [18], who found a lower degree of turfness of common meadow grass in the first years of usage.

The timing of the lawn grass mixture sowing had a clear impact on the turfness of the surface. Spring sowing was found to be the best, while autumn sowing was the worst (Fig. 2). According to Domański [11], the general appearance of grass sward that results from the interaction between morphological features of plants with environmental factors (e.g. temperature and precipitation) is not the only characteristic that adds value to a lawn. Colour and structure of leaf blades are also important morphological traits. Although leaf colour belongs to the group of features that are extremely important for the evaluation of useful- ness of grass species and cultivars for the setting of lawns, these characteristics are difficult to determine (as they require high skills) in studies and scientific papers.

Apart from the season, a range of factors impact the colour of a lawn, such as fertilization, especially with nitrogen [19]. In the presented studies (Fig. 3), together with subsequent doses of sewage sludge, the content of this element respectively increased, thereby improving the colour of grass sward from green-grey on the control object to luscious green with the highest dose of bio-wastes. Studies by Angle [20], and Linde and Hepner [16] also indicated an improvement in the colour of grass sward with incremental doses of composted sewage sludge in comparison with objects on which only nitrogen fertilization was applied. Good development of leaves on plants and their colour and, thus, the appearance and durability of a lawn, depends to a major extent on the content of nutrients in soil. The colour of leaves largely determines the appearance of a lawn and may be modified by a change in habitat and climatic conditions.
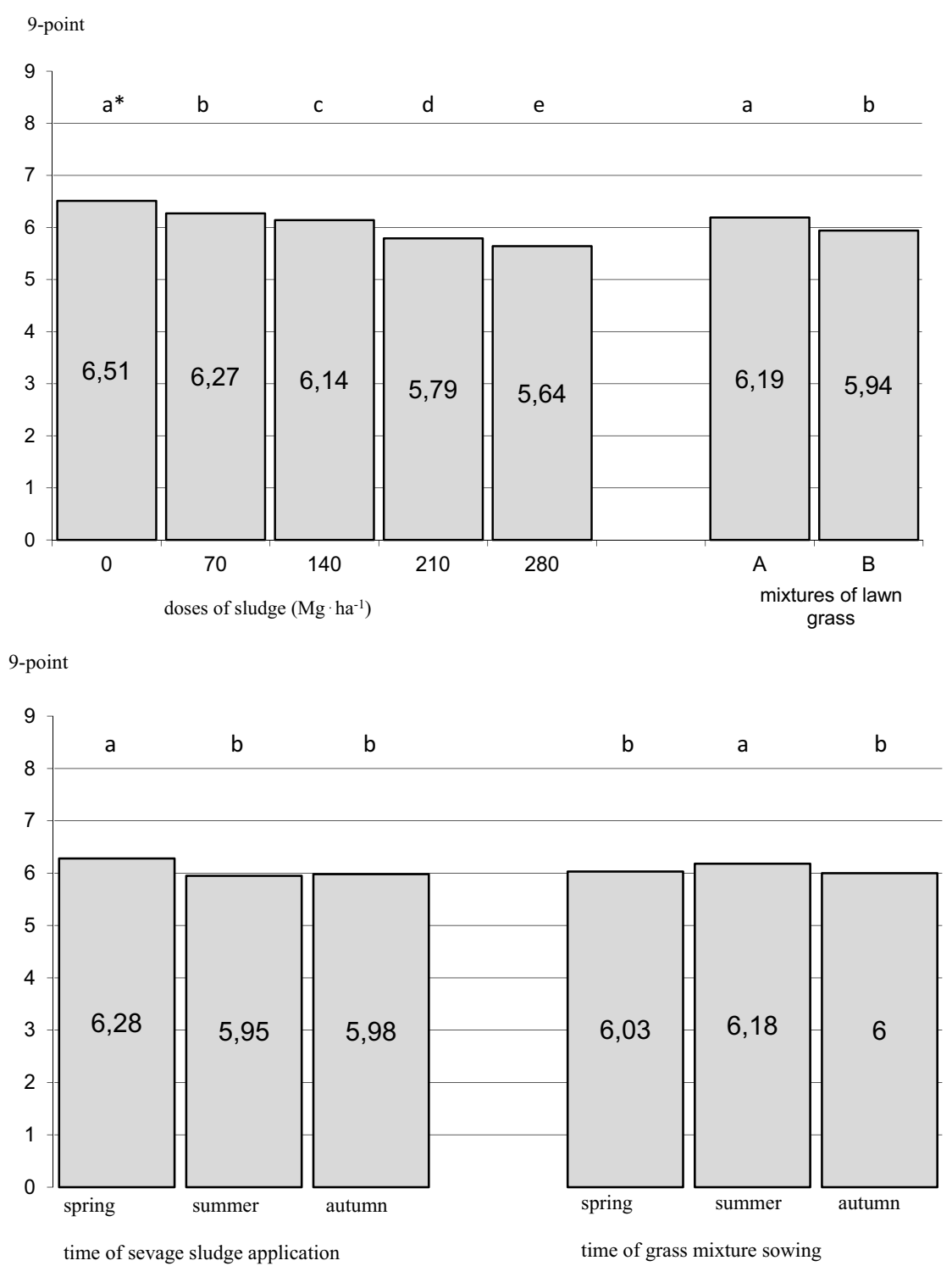

Fig. 4. The effects of sewage sludge dose and mixtures of lawn grass, as well as the term of sewage sludge application and seed sowing on the perfection of leaf blades (mean values from 2006-08).

*a-e - Homogenous groups by Duncan's test 
Fig. 3 also demonstrates that the timing of bio-waste application had an impact on the evaluated feature: the best colour of grass sward was observed on the plots that were fertilized in summer (4.92 on a 9-point scale) with a slightly worse result recorded for the plots fertilized in spring and autumn.

The timing of sowing did not exert any significant impact on the colour of grass sward, and the colour of the lawn was on a comparable green-grey level. Similarly, the type of mixture (fescue or bluegrass) did not play any major role (Fig. 3).

Perfection, i.e. leaf slenderness, is commonly included as a parameter of the evaluation of species and cultivars of lawn grass. Domański $[11,14]$ reports that there are significant differences in slenderness of leaves between cultivars and within species of lawn grasses, which is important when mixtures are designed. It is widely assumed that a slender and delicate leaf is more desired on ornamental lawns.
In studies conducted in 2006-08, this characteristic deteriorated together with the increasing level of fertilization by sewage sludge (Fig. 4). At the highest dose of biowastes, grass had an intermediate (template) leaf blade shape. The most delicate, average-to-slender (6.51 on a 9-point scale) leaf shape was found in grass on the control object (without fertilization). If grass was fertilized with bio-waste, spring application generated the best result. A less desired (template) shape of leaves was observed in grass species (cultivars) that were fertilized in summer and autumn.

Studies carried out by Grabowski et al. [21], Stawiska and Prończuk [22] demonstrate that Festuca rubra has slender and subtle leaves. Agrostis capillaris is also one of the species with the most delicate shape of leaf blade [15]. Studies by Jankowski et al. [15], indicating that lawn grass mixtures in which Festuca rubra predominates and which contain low amounts of Agrostis capillaris demonstrate the desired slenderness of leaves. This was confirmed in the
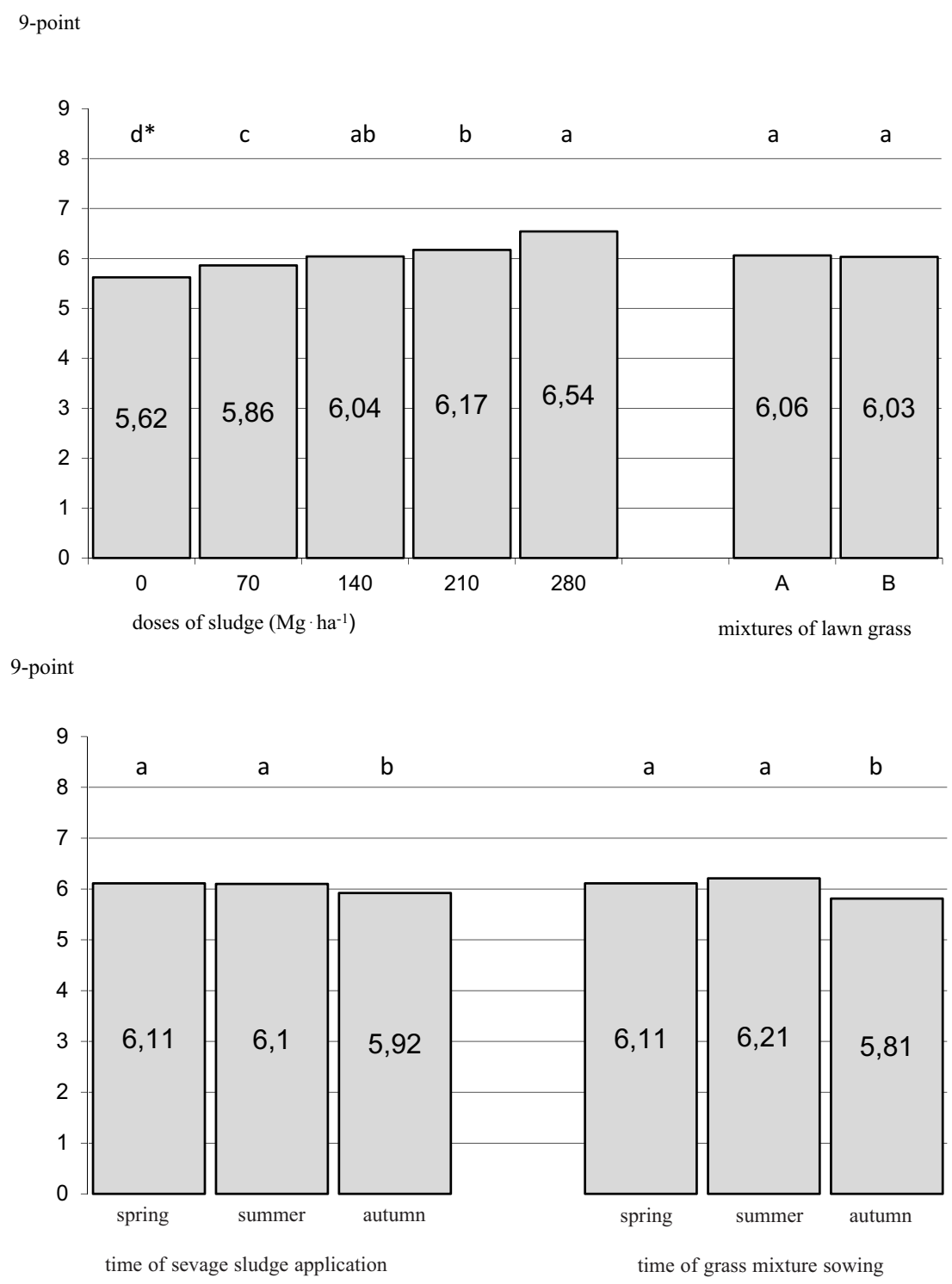

Fig. 5. The effects of sewage sludge dose and mixtures of lawn grass as well as the term of sewage sludge application and seed sowing on general appearance of sward (mean values from 2006-08).

*a-d - Homogenous groups by Duncan's test 
author's own studies in which the fescue mixture had more slender leaves throughout the entire vegetation season than the bluegrass mixture (Fig. 4).

The general appearance is a feature that results from the interaction of genotype with environmental factors [11]. Knowledge of the dynamics of changes in the growth and development of plants in relation to cultivars, species, and mixtures may play a deciding role in the further use of lawns [23]. Valorization of the general appearance constitutes one of the basic characteristics that determine the classification of a given genotype to lawn grasses, this is the trait that best describes the utility value of grass sward.

As the general appearance of grass sward significantly depends on the level of applied sewage sludge doses in the years of full usage of the lawn (Fig. 5), fertilization is justified, especially organic fertilization with sewage sludge. In the analyzed experiment, the attractiveness of the lawn increased together with incremental doses of bio-wastes. The average grass sward was recorded on the control object, whereas the most attractive and average-to-good was recorded for the plots fertilized with $280 \mathrm{Mg} \cdot \mathrm{ha}^{-1}$, especially if this dose was applied in spring or in summer.

The aesthetics of fescue and bluegrass sward was on a comparable level: from acceptable to good (Fig. 5). Martyniak [24] report that the appearance of a lawn in the subsequent years of full usage is influenced by, among other things, the appearance of leaf blades (slenderness), presence of diseases, etc.

The general appearance of grass sward in the studied period (2006-08) depended on timing of lawn grass mixture sowing. The plots sown with mixtures in spring and summer had a better appearance that those sown in autumn (Fig. 5).

\section{Conclusions}

1. The study conducted in the Olsztynskie Lakeland in 2006-08 demonstrated that soil fertilization with sewage sludge can be used throughout the entire vegetation season, namely in spring, summer, and autumn. It positively (especially the highest dose of $280 \mathrm{Mg} \cdot \mathrm{ha}^{-1}$ ) impacts the utility values of grass sward: winter survival, turfness, colour, and aesthetic appearance (general appearance). However, the best utility parameters of the lawn were recorded with spring fertilization of the substrate with sewage sludge.

2. It was found that both tested mixtures of lawn grass (fescue and bluegrass) are useful for sowing extensive lawns, although the fescue mixture had more beneficial parameters (it reacted better to the experimental factors).

3. Among the investigated time-points of sowing (spring, summer, and autumn), better winter survival and turfness were recorded for a lawn set in spring.

4. The use of municipal sewage sludge (bio-wastes) for setting extensive lawns is an inexpensive and ecological method for their use.

\section{References}

1. KAŹMIERCZUK M., KALISZ L. A proposal for extending biological criteria applied in sanitary control of sewage sludge intended for agricultural use. Pol. J. Environ. Stud. 17, (5), 721, 2008.

2. BARAN S. Sevage sludge in agro-ecological economy. Zesz. Prob. Post. Nauk Rol. 499, 15, 2004 [In Polish].

3. ARVAS O., KESKIN B., YILMAZ I. H. Effect of sewage sludge on metal content of grassland soil and herbage in semiarid lands. Turk. J. Agric. For. 37, 179, 2013.

4. SOUSA G., FANGUEIRO D., DUARTE E., VASCONCELOS E. Reuse of treated wastewater and sewage sludge for fertilization and irrigation. Water Sci. Technol. 64, (4), 871, 2011.

5. WYDRO U., WOŁEJKO E., BUTAREWICZ A., ŁOBODA T. Effect of sewage sludge on biomass production and content of macronutriens and chlorophyll in grass mictures. Ecol. Chem. Eng. A. 19, (9), 1015, 2012.

6. WOŁEJKO E., PAWLUŚKIEWICZ B., WYDRO U., ŁOBODA T., BUTAREWICZ A. The effect of sewage sludge on the growth and species composition of the sward and the content of heavy metals in plants and urban soil. Ann. Warsaw Univ. of Life Sci. - SGGW, Land Reclam. 46, (2), 101, 2014.

7. WYSOKIŃSKI A., KALEMBASA S. The yield and utilization coefficient of nitrogen by plants after applying of fresh and composted sewage sludge with mineral and organic additions. Pol. J. Environ. Stud. 20, (6), 1617, 2011.

8. GRABOWSKI K., GRZEGORCZYK S., GŁOWACKAGIL A. The effect of sludge on initial growth and development of lawn grasses in background of different mix types and sowing times. Pol. J. Environ. Stud. 17, (6), 975, 2008.

9. ŁACHACZ A., GRABOWSKI K., KALISZ B., BIEDRZYCKA A. Effects of DANO compost and sewage sludge on some physicochemical properties and organic matter quality of soil under lawn grasses. Pol. J. Environ. Stud. 16, (3B), 299, 2007.

10. SZWEJKOWSKI Z., NOWICKA A., DRAGAŃSKA E. Climate of Mazury Lake District. Part 1. Temperature and atmospheric precipitations in the 45-year period of 1951-1995. Fragm. Agronomica. XVIX 2, (74), 285, 2002 [In Polish].

11. DOMAŃSKI P. Methods for analysis of economic value of field crops cultivars. COBORU Słupia Wielka. I, 1-33, 1998 [In Polish].

12. GARLING D. C., BOEHM M. J. Temporal effects of compost and fertilizer applications on nitrogen fertility of golf course turfgrass. Agron. J. 93, 548, 2001.

13. LOSCHINKOHL C., BOEHM M. J. Composted biosolids incorporation improves turfgrass establishment on disturbed urban soil and reduces leaf rust severity. Hortscience. 36, 790, 2001.

14. DOMAŃSKI P. Sward grasses: red fescue, Kentucky bluegrass, perennial ryegrass. Syntesis of varietal experiment. COBORU Słupia Wielka. 1189, 1-40, 2001 [In Polish].

15. JANKOWSKI K., JODEŁKA J., CIEPIELA G. A., KOLCZAREK R. Quality assessment of lawn grasses. Pam. Puł. 125, 343, 2001 [In Polish].

16. LINDE D. T., HEPNER L. D. Turfgrass seed and sos establishment on soil amended with biosolids compost. Hort Technology. 15, (3), 577, 2005.

17. RADKOWSKI A., STYRC N. Estimation of perennial ryegrass value in amenity cultivation under two methods of exploitation. Zesz. Nauk. UP we Wrocławiu. Roln. LXXXVIII, 545, 261, 2006 [In Polish]. 
18. PROŃCZUK S., PROŃCZUK M. Search of grass species and cultivars for ecological lawns. Zesz. Nauk. UP we Wrocławiu, Roln. LXXXVIII, 545, 241, 2006 [In Polish].

19. BÜGILI U., ACIKGOZA E. Year round nitrogen fertilization effects on growth and quality of sports turf mixtures. Journal Plant Nutrients. 28, 299, 2005.

20. ANGLE J. S. Sewage sludge compost for establishment and maintance of turfgrass. Handbook of integrated pest management for turf and ornamentals: pp. 51, 1994.

21. GRABOWSKI K., GRZEGORCZYK S., KWIETNIEWSKI H. The evaluation of usefulness of Grass species and varieties for recreational lawns in the
Masurian Lakeland conditions. Biul. IHAR 225, 295, 2003 [In Polish].

22. STAWISKA E., PROŃCZUK S. Expression of cultivar traits in turf grass mixtures. Zesz. Nauk. UP we Wrocławiu. Roln. LXXXVIII, 545, 275, 2006 [In Polish].

23. GRABOWSKI K., GRZEGORCZYK S., KWIETNIEWS$\mathrm{KI} \mathrm{H}$. Usefulness of 10 grasses mixtures for sowing on sport playing fields. Zesz. Nauk. UP we Wrocławiu. Roln. LXXXVIII, 545, 95, 2006 [In Polish].

24. MARTYNIAK D. The effect of sowing density of Festuca rubra L. turf compactness and general aspect. Zesz. Nauk. UP we Wrocławiu. Roln. LXXXVIII, 545, 165, 2006 [In Polish]. 